\title{
Chemical composition and water quality of surface waters in Ukraine
}

\author{
V. Osadchy, N. Osadcha \& Ju. Nabyvanets \\ Ukrainian Hydrometeorological Research Institute, Kiev, Ukraine.
}

\begin{abstract}
Summarizing of last decade data concerning Ukraine's surface waters chemical composition have been carried out. Changes of mineralization, $\mathrm{pH}$, mineral forms of phosphorus and nitrogen, heavy metals and humic substances in water of main river basins were shown.

It was found, that in basins of Zapadny Bug, Dnieper, Danube and Seversky Donets the tendency of $\mathrm{pH}$ increase is being observed for the long time. It also should be mentioned that almost for all studied river basins of Ukraine decreasing of phosphorus mineral forms concentrations were identified. That finding allows concluding about obvious discontinuance of global process of surface water eutrophication by phosphorus compounds. Also the comparative analysis of data sets obtained in early 60-s and for period of 1995-2000 indicated the tendency of $\mathrm{N}_{\min }$ and $\mathrm{NH}_{4}{ }^{+}$decreasing almost in 2 times.

Relatively high concentrations of dissolved organic matter would be considered as a positive factor of water selfpurification from toxic forms of heavy metals.From another hand, results of field observation as well as computer thermodynamic modeling data have shown that under physicochemical conditions of Ukrainian surface waters trace metals are thermodynamically unstable in a phase of solution.

Summarizing results of a long-term data processing concerning distribution of different classes of chemical substances in water, suspended matter, biological materials and sediments we would conclude, that despite significant man-caused impact Ukrainian surface water still possesses the self-purification ability.
\end{abstract}

\section{Introduction}

Eight large river basins are distinguished at the territory of Ukraine comprising 71,000 rivers and streams with the total length of $248000 \mathrm{kms}$. The Dnieper is a principal waterway of Ukraine with its basin of $509000 \mathrm{~km}^{2}$. Nowadays the 


\section{Environmental Health Risk}

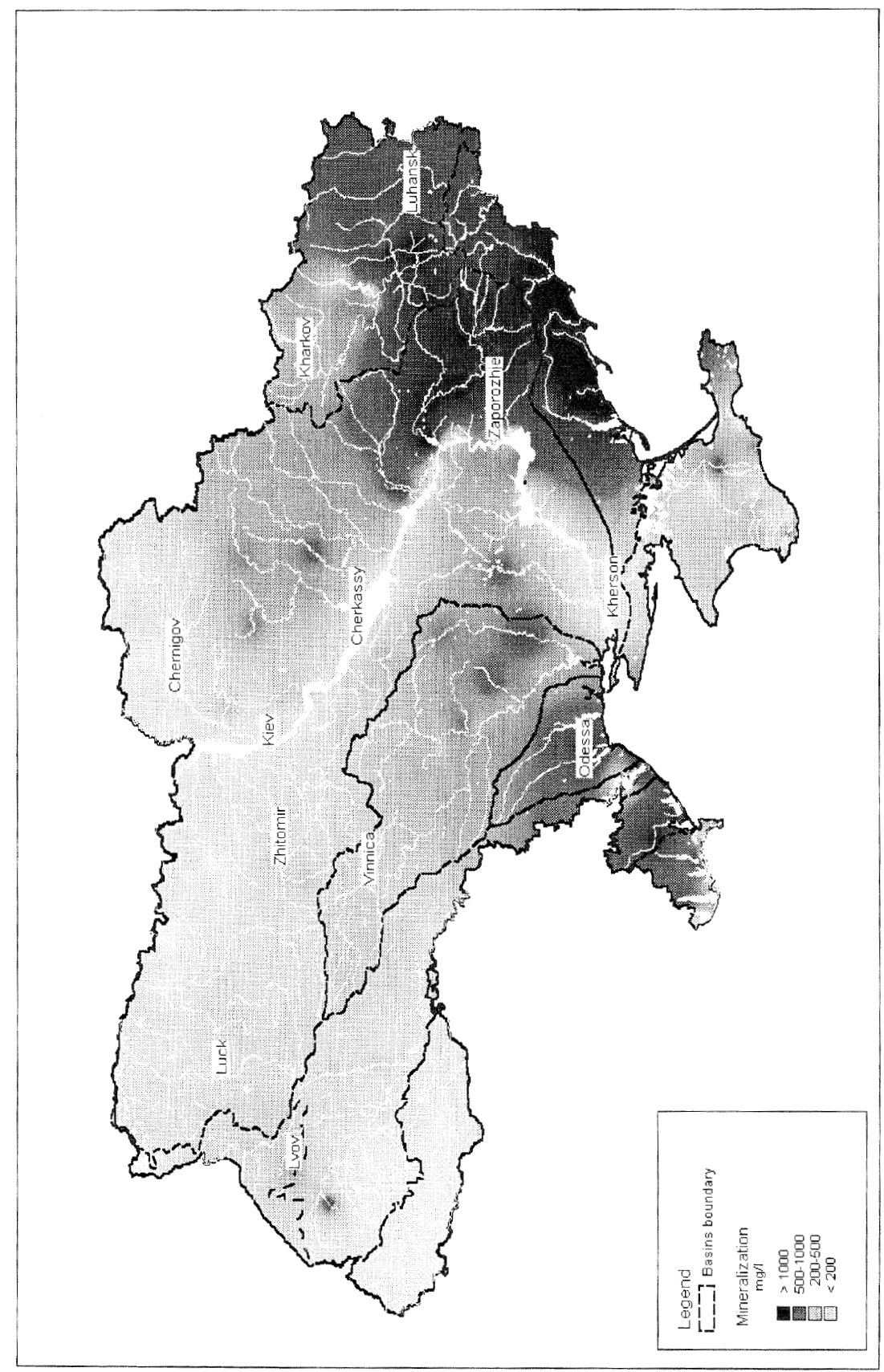


Dnieper is almost completely regulated and represents cascade of 6 reservoirs (Kievskoe, Kanevskoe, Kremenchugskoe, Dneprodzerzhinskoe, Dneprovskoe and Kahovkskoe), located from north to south. The Dniester, Danube, Severskiy Donets and Youzhniy Bug also belong to the category of big rivers.

Physiographic, climate, geological and soil conditions of Ukraine are quite various. This leads to the versatility in surface water chemical composition. In general according to mineralization Ukrainian rivers can be divided into several groups: rivers with minor water mineralization - up to $200 \mathrm{mg} / \mathrm{dm}^{3}$; rivers with medium water mineralization $-200-500 \mathrm{mg} / \mathrm{dm}^{3}$; rivers with increased water mineralization - 500-1000 $\mathrm{mg} / \mathrm{dm}^{3}$ and rivers with saltish water - more than $1000 \mathrm{mg} / \mathrm{dm}^{3}$ (Fig.1). As it can be seen from Fig.1, the majority of rivers have the medium water mineralization. In general distinctive changes in salinity from north-west to south-east could be observed. It is caused by chemical composition of bed rocks and soils, and climatic factors as well. The least mineralized waters are those of the Dnieper basin (with exception of some tributaries), and also Carpathian tributaries of the Danube. Saltish waters include the Severskiy Donets basin (mineralization is over $1000 \mathrm{mg} / \mathrm{dm}^{3}$ ) and rivers of Azov region with mineralization greater than $2000 \mathrm{mg} / \mathrm{dm}^{3}$. In respect to chemical composition, fresh water is hydrocarbonate calcium type, and saltish is sulphate magnesium type.

The analysis of average annual runoff of the Ukrainian river basins shows that the last decade of the XX century was characterized with increased water content.

\section{Materials and Methods}

This work represents integrated materials, received by Hydrometeorological service of Ukraine observation network in 1990-2000 as well as results of the authors' experimental investigations.

Identification of natural waters chemical content was performed in compliance with national and international standards. Determination of humic substances content was performed on the basis of Sirotkina method (Sirotkina $[1,2]$ ).

\section{Results and Discussion}

\subsection{Water mineralization}

Runoff volume is one of the main natural factors, determining water mineralization. Runoff increase, as it is typical for the most of the European rivers, leads to decrease of the water mineralization. However, for waters of saltish type this dependence isn't very important.

Over-regulation of the Dnieper, construction of reservoirs cascade has led to increase of mineralization and content of some major ions in the lower part of cascade. Thus during the last 40 years the upper limit of mineralization in last Kahovskoe reservoir has increased by $100 \mathrm{mg} / \mathrm{dm}^{3}$ and reached about 450 $\mathrm{mg} / \mathrm{dm}^{3}$. At the same time the lower limit of mineralization has increased from 


\section{Environmental Health Risk}

$150 \mathrm{mg} / \mathrm{dm}^{3}$ to $300 \mathrm{mg} / \mathrm{dm}^{3}$. It was probably caused by the high soluble salts accumulation due to the evaporative concentration.

\subsection{Water $\mathrm{pH}$}

Analysis of results, obtained during the last 10 years, showed the existence of stable tendency of hydrogen index increasing in basins of the Dnieper, Danube, Zapadniy Bug and Severskiy Donets. Such process might be caused by both natural factors and wastewater pollution. As example, Fig 2.displays the water $\mathrm{pH}$ change in the Danube river, Ismail.

It is a well-known fact, that the hydrogen index is determined by carbonate balance status:

$\mathrm{H}_{2} \mathrm{O}+\mathrm{CO}_{2} \geqslant \mathrm{H}_{2} \mathrm{CO}_{3} \geqslant \mathrm{H}^{+}+\mathrm{HCO}_{3}^{-} \geqslant 2 \mathrm{H}^{+}+\mathrm{CO}_{3}{ }^{2-}$.

Taking into consideration the first stage of the carbonic acid dissociation in accordance with law of active masses, we have:

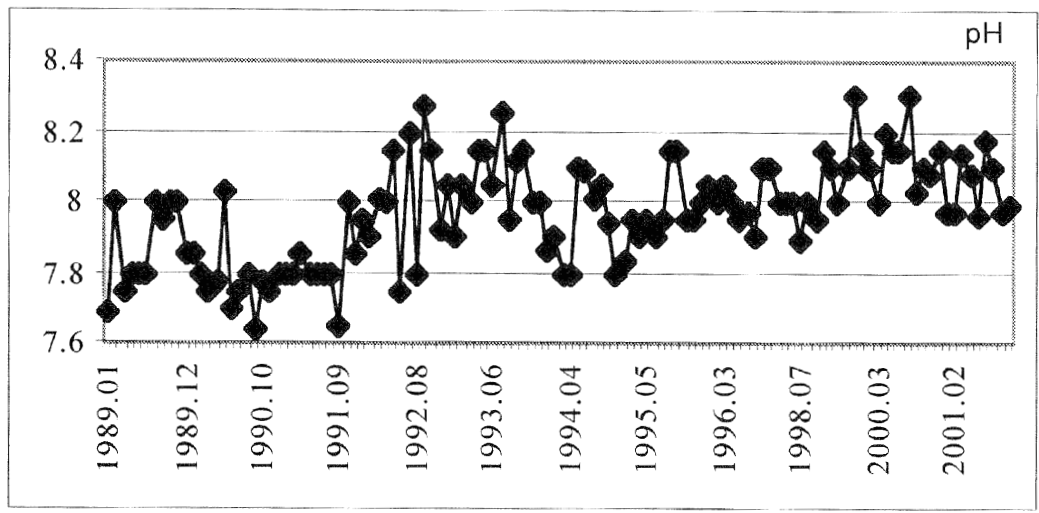

Figure 2: Dynamics of hydrogen index change in the Danube river, Ismail

$$
p H=p K_{1}+\lg \frac{\gamma_{\mathrm{HCO}_{3}{ }^{-}\left[\mathrm{HCO}_{3}{ }^{-}\right]}}{\left[\mathrm{H}_{2} \mathrm{O}\right]\left[\mathrm{CO}_{2}\right]} .
$$

Therefore, water $\mathrm{pH}$ is directly proportional to hydrocarbonate ion concentration and is inversely proportional to the $\mathrm{CO}_{2}$ concentration.

Analysis of the $\mathrm{CO}_{2}$ concentration changes in the Danube near Ismail, shows tendency of $\mathrm{CO}_{2}$ decrease in water. At the same time correlation coefficient between water $\mathrm{pH}$ and the $\mathrm{CO}_{2}$ content amounted to $0.75(\mathrm{n}=122)$.

Based on the eqn (1) we have calculated water $\mathrm{pH}$ values for the Danube water, Ismail, corresponding to the $\mathrm{CO}_{2}$ concentration natural changes from 0,15 $\mathrm{mmol} / \mathrm{dm}^{3}$ to $0,03 \mathrm{mmol} / \mathrm{dm}^{3}$. For $\mathrm{HCO}_{3}{ }^{-}$concentration and $\gamma_{\mathrm{HCO}_{3} \text {. value we used }}$ their average in 1989-2000. Obtained results show that five times decrease of $\mathrm{CO}_{2}$ concentration will lead to water $\mathrm{pH}$ increase by 0,7 .

Water $\mathrm{pH}$ increase, as important component of carbonate calcium balance, leads to its shift towards calcium carbonate $\left(\mathrm{CaCO}_{3}\right)$ formation with possible further removal from liquid phase. In order to evaluate water saturation degree by $\mathrm{CaCO}_{3}$ saturation index ( $\mathrm{SI}$ ) was used. This index was determined as: 


$$
\mathrm{SI}_{\mathrm{CaCO}_{3}}=\lg \left(\frac{a_{\mathrm{Ca}^{2+}} \cdot a_{\mathrm{CO}_{3}^{2-}}}{K_{\mathrm{CaCO}_{3}}}\right) \text {, }
$$

where a - ions' activity.

The MINTEQA2 software (Allison [3]) was employed to calculate the Danube water saturation with tiff $\left(\mathrm{CaCO}_{3}\right)$. Calculation results showed (Fig.3) that saturation index in all cases is positive, i.e., system is oversaturated with calcium carbonate $\left(\mathrm{CaCO}_{3}\right)$. As long as $\mathrm{SI}$ is a logarithm, degree of solution oversaturation practically amounted to 1,5-3 times. Such metastable state is quite typical for natural waters and may maintain for a long period of time.

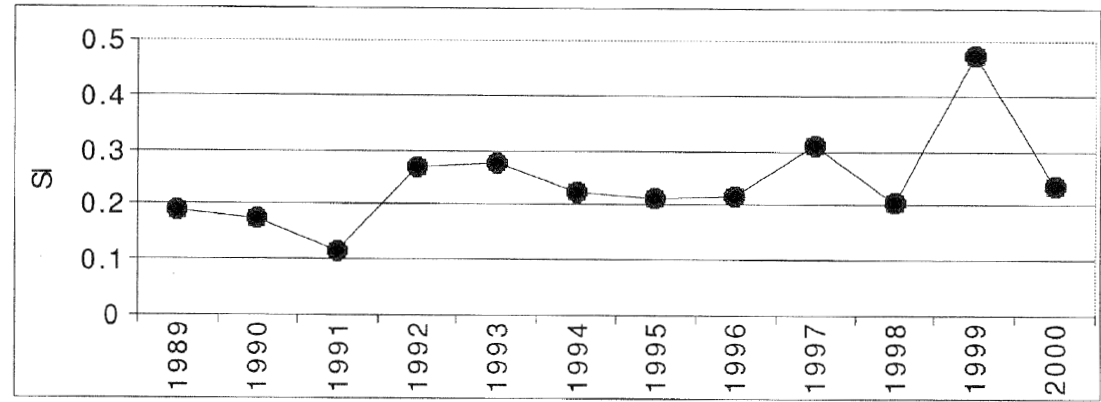

Figure 3: Changing of the saturation index (SI) with calcium carbonate, the Danube river, Ismail.

There is a hypothesis about climatic nature of above-mentioned changes. It was determined that changes of average annual air temperature towards warming take place in Ukraine. These changes for centenary period have amounted to 0,7 $-0,9^{\circ} \mathrm{C}$ in the Woodlands and the Forest-steppe, and $0,2-0,3{ }^{\circ} \mathrm{C}$ in the Steppe zone. The temperature increase occurs within cold period while summer temperature changes were insignificant. Generally, the period of warm water temperatures suitable for phytoplankton development extends during the year. As is well known, during phytoplankton vital functions dissolved $\mathrm{CO}_{2}$ is being consumed and its concentration in water substantially decreased, which leads to water $\mathrm{pH}$ increase (Kureyshevich [4]).

\subsection{Phosphorus and nitrogen compounds}

During the period of 1965-1995 increase of mineral phosphorus content was determined for Ukrainian waters, allowing concluding about process of superficial waters global euthrophication. The highest phosphate ions value was detected in the Severskiy Donets. In 1990 their average annual concentrations amounted to $0,35 \mathrm{mgP} / \mathrm{dm}^{3}$. Since 1995 , process of further increase of phosphate ions concentrations in Ukrainian rivers terminated (Fig. 4).

Today decrease and stabilization of mineral phosphorus concentration is detected practically in all water objects. Most of researchers consider economic recession in our country as a possible reason of this process (National... [5]). In recent years Severskiy Donets appeared to be the most polluted with $\mathrm{PO}_{4}{ }^{3-}$ 


\section{Environmental Health Risk}

compounds, however, their average annual concentration in 2000 amounted to $0,28 \mathrm{mgP} / \mathrm{dm}^{3}$. At present time the maximum permissible concentration for phosphorus mineral forms has not yet been established in Ukraine, but it is considered that concentration of $0,05 \mathrm{mgP} / \mathrm{dm}^{3}$ is ultimate for preventing of ecological balance damage and anthropogenic euthrophication of the water basins. Despite sufficient reduction of phosphate content level, only the water of the Danube and the Dniester and the Crimean rivers now meet these requirements.

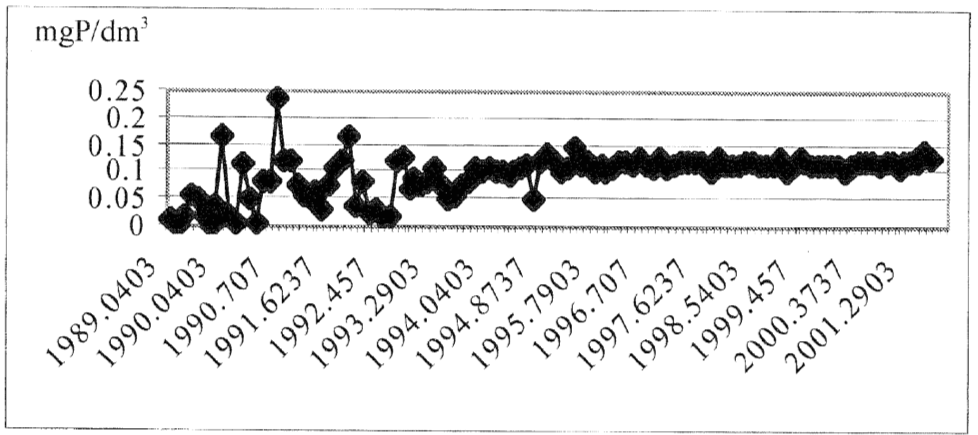

Figure 4: Dynamics of the phosphate content changes in the Dnieper river water, Kherson.

Content of nitrogen mineral forms ( $\left.\mathrm{NH}{ }_{4}^{+}, \mathrm{NO}_{2}{ }^{-}, \mathrm{NO}_{3}{ }^{-}\right)$in Ukrainian surface water in 2000 is represented on Fig. 5. Evidently, the Eastern part of Ukraine, Azov region rivers, was characterized with worst conditions regarding mineral forms of nitrogen content. In Azov region average annual concentrations of $\mathrm{N}_{\text {min }}$ vary within $5,5-1,9 \mathrm{mgN} / \mathrm{dm}^{3}$. Crimean rivers and Zapadniy Bug with its wastewater from L'vov are highly polluted too. Average annual Nmin concentrations have amounted there up to $2 \mathrm{mgN} / \mathrm{dm}^{3}$ and more.

It should be noticed that in respect to sufficient annual variations in nitrogen compounds concentration quite powerful mechanisms take place in water objects promoting the nitrogen removal from water phase to bottom sediments. That was proved by long-term observations of spatial distribution of the nitrogen compounds along the Dnieper reservoirs cascade.

\subsection{Humic substances}

One of specific features of the Dnieper basin's surface water is a high content of humic substances playing principal role in formation of organic substances flow. According to [(Tseeb [6]) data, carbon of humic acids in Kiev reservoir correspondingly to $\mathrm{C}_{\text {org., }}$ amounts to $50-85 \%$.

In humic substances the most common fractions such as humic (HA) and fulvic acids (FA) were studied in 1994-2001. The HA content in the Dnieper reservoirs varied within $0,16-1,92 \mathrm{mg} / \mathrm{dm}^{3}$ while FA concentration varied from 3,2 to $31,8 \mathrm{mg} / \mathrm{dm}^{3}$. HA/FA ratio was $1: 16$, which is typical for natural water and is caused by much higher solubility of FA. In seasonal aspect maximal 
Environmental Health Risk 21

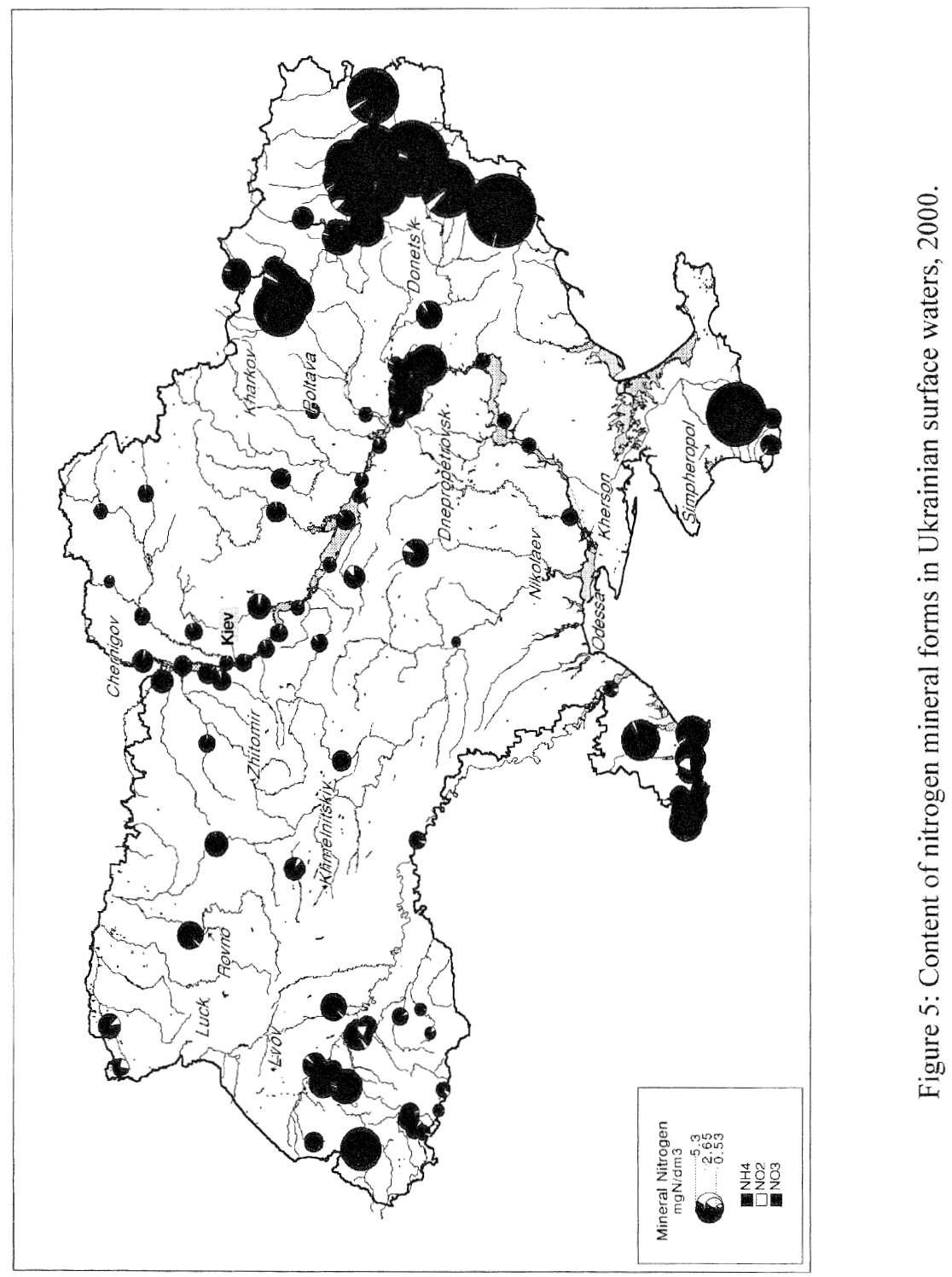




\section{Environmental Health Risk}

concentrations of humic substances were determined during the spring flood and gradually decreased to their minimum during summer low water.

Spatial distribution of humic substances along the Dnieper reservoir cascade is determined by geographical position of the reservoirs and their hydrologic characteristics. Peak values were detected in upper reservoirs with the most developed river network. Humic substances content in downstream reservoirs is generally affected by the incoming from upstream reservoirs, and also by internal processes development. Calculated trends of humic substances content changes during spring flood appear to be an evidence of their concentrations decrease from north to south. Substantial influence on formation of organic matter runoff is made by flood advancement from upper to lower reservoirs. Thus, increased amounts of humic substances settled in Kievskoe reservoir in spring, and adjacent Kanevskoe reservoir, were generally detected in summer. By the end of September they would reach Kremenchugskoe reservoir. Later entry of floodwater to lower part of the cascade caused by the fact that such reservoirs as Kremenchugskoe and Kahovskoe (the last one) reservoir are of minor water flow. Their water cycle generally includes 85-130 days (Denisova [7]). The highest concentrations of $\mathrm{HA}$ in reservoirs of middle and lower Dnieper are usually determined in autumn/winter.

Humic substances content in Dnieper reservoirs is generally conditioned on Dnieper basin bogging. Basin of Dnieper's main tributary Pripiat is the most swapped. Pripiat waters containing humic substances influence not only the upper reservoir, but also water quality of entire Dnieper cascade. In the summer of 1998 the concentration of HA concentration in Pripiat water reached about 6 $\mathrm{mg} / \mathrm{dm}^{3}$ and FA concentration - over $50 \mathrm{mg} / \mathrm{dm}^{3}$. Accordingly, concentration of humic substances in Kiev reservoir and other Dnieper reservoirs has almost doubled which caused sufficient problems in water supply of Dnieper region cities. The results obtained show that this phenomenon was caused by the water level of Pripiat river fluctuation.

In order to assess a degree of Pripiat river water level influence on Dnieper river water system quality we have calculated the humic substances inflow from Pripiat river basin during the years 1995 - 2000. Results are presented in Table 1.

Table 1. Humic acids and fulvic acids inflow with Pripiat river water.

\begin{tabular}{|c|c|c|c|c|c|c|c|c|c|c|c|}
\hline \multirow{3}{*}{ Year } & \multirow{3}{*}{$\begin{array}{l}\text { Water } \\
\text { flow, } \\
\mathrm{km}^{3}\end{array}$} & \multicolumn{4}{|c|}{ High water } & \multicolumn{4}{|c|}{ Low water } & \multicolumn{2}{|c|}{ Total per year } \\
\hline & & \multicolumn{2}{|c|}{$\mathrm{HA}$} & \multicolumn{2}{|c|}{ FA } & \multicolumn{2}{|c|}{$\mathrm{HA}$} & \multicolumn{2}{|c|}{$\overline{\mathrm{FA}}$} & \multirow{2}{*}{$\begin{array}{c}\text { HA } \\
10^{3} \\
\text { tones }\end{array}$} & \multirow{2}{*}{$\begin{array}{c}\mathrm{FA} \\
10^{3} \\
\text { tones }\end{array}$} \\
\hline & & $\begin{array}{l}10^{3} \\
\text { tones }\end{array}$ & $\%$ & $\begin{array}{l}10^{3} \\
\text { tones }\end{array}$ & $\%$ & $\begin{array}{l}10^{3} \\
\text { tones }\end{array}$ & $\%$ & $\begin{array}{l}10^{3} \\
\text { tones }\end{array}$ & $\%$ & & \\
\hline 1995 & & 5,3 & 6 & 164,1 & 79,9 & 2,1 & 284 & 41.3 & 20,1 & 7,4 & 205,4 \\
\hline 19 & & 8,9 & 7 & 0 & 72,0 & 2,7 & 3,3 & 63,2 & 28 & 11 & 226,0 \\
\hline 1997 & & 5,4 & 37,0 & 127,8 & 41,2 & 9,2 & 63,0 & 182,3 & 58 & 14,6 & 310,1 \\
\hline 1998 & & 2 & 6 & 279,4 & 50,9 & 20,8 & 48,4 & 269,1 & 49,1 & 43,0 & 548,5 \\
\hline 1999 & &, 4 & 83,5 & 426,3 & 82,0 & 6,0 & 15,5 & 93,3 & 18,0 & 36,4 & 519,6 \\
\hline 2000 & 15,07 & 12,2 & 78,7 & 148,8 & 61,9 & 3,3 & 21,3 & 91,7 & 38,1 & 15,5 & 240,5 \\
\hline
\end{tabular}

The Table 1 data show that the most part (62-82\%) of the humic substances is flown into a riverbed at spring, while the water level is high. A year distribution for the HA and the FA differs insignificantly. During the observation period only 
the 1997 and the 1998 data were deviated from the usual. During the mentioned years the high water levels washed out about $40 \%$ and $50 \%$ of the year humic substances drain due to the extreme freshet nature of the Pripiat river hydrological regime. In Pripiat river basin significant water discharge increase occurred for the last 10 years. That phenomenon caused washout of humic substances from soils.

\subsection{Heavy metals}

The results obtained during the last decade show a considerable decreasing of the heavy metals (HM) in the surface water in Ukraine. This phenomenon correlates with the industrial production decrease in the country (National...[5]).

Both dissolved and suspended forms of HM were studied. By the relative suspended metal forms content the HM could be ranged in following order: $\mathrm{Fe}>\mathrm{Mn}>\mathrm{Pb}>\mathrm{Ni}>\mathrm{Co}>\mathrm{Cu}>\mathrm{Zn}>\mathrm{Cd}$. A direction of inter-phase HM distribution in the "water-suspended matter" system is determined by the individual chemical properties for each of the metal, by a quantity of the suspended material, its granulometric and mineral content, and also by the water environment physicalchemical conditions. The suspended substances with particles size of $0.05 \mathrm{~mm}$ and less are characterized with the highest sorption capacity.

It has been found that the HM highest concentrations are associated with the fine silt deposits (Table 3).

Table 3. Heavy metals content in the surface layer of Kakhovskoe reservoir sediments.

\begin{tabular}{|c|c|c|c|c|c|c|c|c|}
\hline Fraction & $\begin{array}{c}\% \text { of } \\
\text { organic } \\
\text { matter }\end{array}$ & $\begin{array}{c}\mathrm{Fe}, \\
\mathrm{mg} / \mathrm{kg}\end{array}$ & $\begin{array}{c}\mathrm{Mn}, \\
\mathrm{mg} / \mathrm{kg}\end{array}$ & $\begin{array}{c}\mathrm{Zn}, \\
\mathrm{mg} / \mathrm{kg}\end{array}$ & $\begin{array}{c}\mathrm{Cu}, \\
\mathrm{mg} / \mathrm{kg}\end{array}$ & $\begin{array}{c}\mathrm{Pb}, \\
\mathrm{mg} / \mathrm{kg}\end{array}$ & $\begin{array}{c}\mathrm{Ni}, \\
\mathrm{mg} / \mathrm{kg}\end{array}$ & $\begin{array}{c}\mathrm{Co}, \\
\mathrm{mg} / \mathrm{kg}\end{array}$ \\
\hline Psammitic & \multirow{4}{*}{$\begin{array}{l}1,2 \\
3,0 \\
1,7\end{array}$} & \multirow{4}{*}{$\begin{array}{c}5326,0 \\
10830,0 \\
7385,0\end{array}$} & \multirow{4}{*}{$\begin{array}{l}113,0 \\
162,0 \\
219,0\end{array}$} & \multirow{4}{*}{$\begin{array}{l}22,0 \\
30,0 \\
40,0\end{array}$} & \multirow{4}{*}{$\begin{array}{c}6,0 \\
20,5 \\
13,5\end{array}$} & \multirow{4}{*}{$\begin{array}{c}4,5 \\
10,0 \\
8,0\end{array}$} & \multirow{4}{*}{$\begin{array}{l}18,0 \\
26,0 \\
21,5\end{array}$} & \multirow{4}{*}{$\begin{array}{c}7,5 \\
13,0 \\
10,8\end{array}$} \\
\hline Min. & & & & & & & & \\
\hline Max. & & & & & & & & \\
\hline Aver. & & & & & & & & \\
\hline Aleurite & \multirow{4}{*}{$\begin{array}{l}5,8 \\
8,0 \\
7,0\end{array}$} & \multirow{4}{*}{$\begin{array}{l}12854,0 \\
19034,0 \\
15800,0\end{array}$} & \multirow{4}{*}{$\begin{array}{l}486,0 \\
920,0 \\
754,0\end{array}$} & \multirow{4}{*}{$\begin{array}{c}39,0 \\
54,0 \\
46\end{array}$} & \multirow{4}{*}{$\begin{array}{l}12,0 \\
20,0 \\
17,0\end{array}$} & \multirow{4}{*}{$\begin{array}{l}16,0 \\
20,0 \\
17,0 \\
\end{array}$} & \multirow{4}{*}{$\begin{array}{l}35,0 \\
46,0 \\
41,0\end{array}$} & \multirow{4}{*}{$\begin{array}{l}14,0 \\
18,0 \\
15,0\end{array}$} \\
\hline & & & & & & & & \\
\hline Max. & & & & & & & & \\
\hline Aver & & & & & & & & \\
\hline Pelitic & \multirow{3}{*}{$\begin{array}{l}12,0 \\
19,0 \\
16,0\end{array}$} & \multirow{3}{*}{$\begin{array}{l}22165,0 \\
36758,0 \\
30060,0\end{array}$} & \multirow{3}{*}{$\begin{array}{l}1016,0 \\
1785,0 \\
1538,0\end{array}$} & \multirow{3}{*}{$\begin{array}{c}63,5 \\
115,5 \\
96,0\end{array}$} & \multirow{3}{*}{$\begin{array}{l}29,0 \\
52,0 \\
42,0\end{array}$} & \multirow{3}{*}{$\begin{array}{l}26,0 \\
41,0 \\
32,0\end{array}$} & \multirow{3}{*}{$\begin{array}{l}50,0 \\
82,5 \\
70,0\end{array}$} & \multirow{3}{*}{$\begin{array}{l}21,6 \\
39,0 \\
31,0\end{array}$} \\
\hline Min. & & & & & & & & \\
\hline $\begin{array}{l}\text { Max. } \\
\text { Aver }\end{array}$ & & & & & & & & \\
\hline
\end{tabular}

Research on the heavy metals content in various granulometric fractions of the bottom deposits shows that as the fraction dimensions decreasing the concentration involves practically all the metals concentrations increasing. The fractions with the sizes of $>0.1 \mathrm{~mm}$ are represented by a sand material, the fractions are characterized by minimal content of the elements under the research and practically do not participate in the processes of the water self cleaning. The 


\section{Environmental Health Risk}

heavy metals maximum concentrations are observed at the fine dispersion deposits (starting at $.05 \mathrm{~mm}$ and less).

In order to study the levels of technogenic impact on the Dnieper reservoirs cascade the HM vertical distribution in cores of the bottom deposits was investigated (Fig.6). The obtained results showed that the Dneprovskoe and Kakhovskoe reservoirs, located within Ukrainian large industrial areas, are mostly polluted.
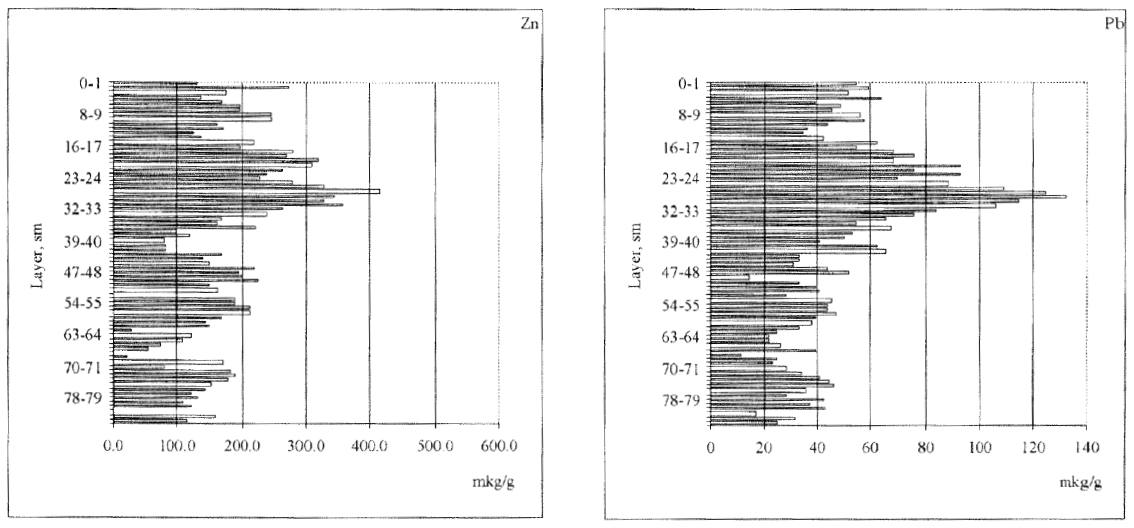

Figure 6: Vertical distribution of $\mathrm{Pb}$ and $\mathrm{Zn}$ in core of Dneprovskoe reservoir.

\section{References}

[1] Sirotkina I.S., Systematical schemes of analysis for the natural waters organic matters, Moscow: Nauka, V.5, pp.196-203, 1977, (in Russian).

[2] Alken G.R., McKnight D.M., Wershaw R.L. \& Maccarthy P., Humic substances in Soil, Sediment and Water, New York: Willey, 1985.

[3] Allison J.D., Brown D.S., Novo-Gradac K.J., MINTEQA2/PRODEFA2, a geochemical assessment model for environmental systems: Version 3.0 user's manual. U.S. Environmental Protection Agency, Athens, GA, 1990.

[4] Kureyshevich A.V., Sirenko L.A., Influence of phytoplankton on the forming of water $\mathrm{pH}$ value (on an example of the Dnieper reservoirs), Hydrobiol. Journ., 30 (2), pp.7-21,1994, (in Russian).

[5] National Report on the State of Environment in Ukraine, Ministry of Environment and Natural Resources, Kiev: Raevsky Scientific Publishers, 2000.

[6] Tseeb Ya.Ya., Maystrenko Yu.G., Kievskoe reservoir, Kiev: Naukova dumka, 1972, (in Russian).

[7] Denisova A.I., Timchenko V.M., Hakhshina E.P. and others, Hydrology and hydrochemistry of the Dnieper reservoirs, Kiev: Naukova dumka, 1989(in Russian). 